Cinémas

Revue d'études cinématographiques

Journal of Film Studies

\title{
Farmers, Phantoms and Princes. The Canadian Pacific Railway and Filmmaking from 1899-1919
}

\section{Greg Eamon}

Volume 6, numéro 1, automne 1995

Le cinéma muet au Québec et au Canada : nouveaux regards sur une pratique culturelle

URI : https://id.erudit.org/iderudit/1000957ar

DOI : https://doi.org/10.7202/1000957ar

Aller au sommaire du numéro

Éditeur(s)

Cinémas

ISSN

1181-6945 (imprimé)

1705-6500 (numérique)

Découvrir la revue

Citer cet article

Eamon, G. (1995). Farmers, Phantoms and Princes. The Canadian Pacific Railway and Filmmaking from 1899-1919. Cinémas, 6(1), 11-32.

https://doi.org/10.7202/1000957ar
Résumé de l'article

Le développement des images animées coïncide avec le développement d'importantes campagnes de publicité de la compagnie de chemin de fer Canadien Pacifique. Cette compagnie a vite réalisé le potentiel du nouveau média et misé sut la fascination du public pour le train et le mouvement. En vue d'encourager l'immigration et l'établissement dans l'ouest du Canada, la compagnie a mis en place un vaste système de promotion qui inclut l'utilisation des films. La réalisation des films du Canadien Pacifique se répartit en deux grandes catégories : les films destinés de façon spécifique à des fonctions d'éducation et d'information et les films à vocation de divertissement. Le Canadien Pacifique n’a pas défini au préalable le type de réalisation, mais il facilita une production reliée à l'attraction commerciale de l'époque. 


\title{
Farmers, Phantoms and Princes. The Canadian Pacific Railway and Filmmaking from 1899-1919
}

\section{Greg Eamon}

\begin{abstract}
RÉSUMÉ
Le développement des images animées coïncide avec le développement d'importantes campagnes de publicité de la compagnie de chemin de fer Canadien Pacifique. Cette compagnie a vite réalisé le potentiel du nouveau média et misé sur la fascination du public pour le train et le mouvement. En vue d'encourager l'immigration et l'établissement dans l'ouest du Canada, la compagnie a mis en place un vaste système de promotion qui inclut l'utilisation des films. La réalisation des films du Canadien Pacifique se répartit en deux grandes catégories: les films destinés de façon spécifique à des fonctions d'éducation et d'information et les films à vocation de divertissement. Le Canadien Pacifique n'a pas défini au préalable le type de réalisation, mais il facilita une production reliée à l'attraction commerciale de l'époque.
\end{abstract}

\section{ABSTRACT}

The development of motion pictures coincided with the development of active publicity campaigns by the Canadian Pacific Railway Company. It did not take the CPR long to realize the potential of the new medium and capitalize on the public's fascination with train and motion. In order to encourage immigration and settlement to western Canada, the company developed an extensive system of promotion which included the use of films. CPR filmmaking fell broadly into two categories, those which were designed with a specific intent to educate, inform and persuade and those which were 
primarily intended as entertainment. If CPR did not define the type of filmmaking rather it facilitated the production of contemporary appeal.

\section{Moving Pictures and Railroads}

The history of cinema is filled with innumerable stories of audience reaction to images of locomotives seeming to rush at them through the screen. In addition to trains, street cars, carriages and ships were all popular subjects in early films. This fascination with travel and motion is evidenced by the incredible number and variety of devices and patents in which the impression of travel was created or recreated via moving images. In fact, early exhibition history contains many examples of the use of moving images in a wide variety of simulators from the inception of motion pictures.

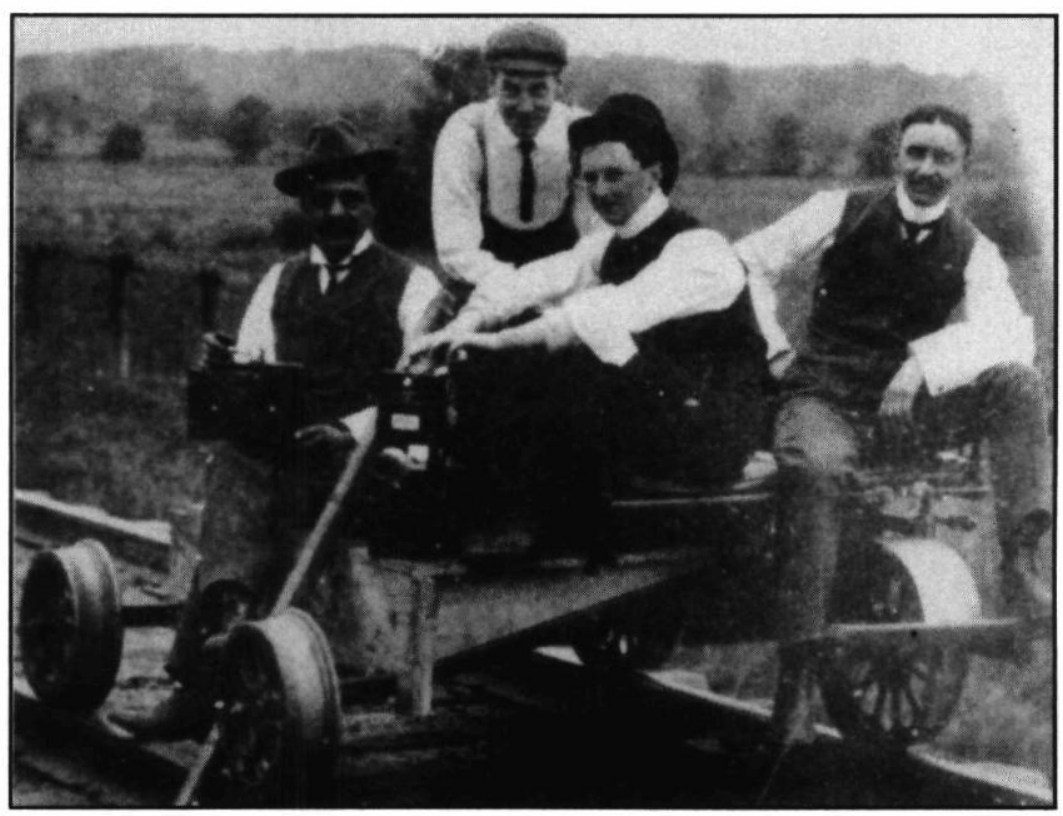

The Bioscope Company Operating along the CPR Company's lines (near Dorval, Québec). From left to right: F. Guy Brandford, Cliff Denham, T. Bell (CPR photographer), Joseph Rosenthal Collection National Archives of Canada 
The earliest of these was proposed by the British film pioneer, Robert Paul along with the novelist and futurist, H. G. Wells. The 1895 preliminary patent application describes a "Time Machine" whereby the traveller would travel through time by viewing images of that period projected on the screen in front of them. Another example is found at the Paris 1900 Exhibition, "Le Ballon Cinéorama," in which passengers sat on a round platform resembling a wicker basket and viewed hand-coloured images, filmed from the air, projected beneath them in a circle.

On 28 May 1905, at Kansas City's Electric Park, one of the most popular (and commercially successful) of these type of attractions, the Hale's Tour and Scenes of the World' first opened. In these amusements the "passenger" paid a "fare" to a uniformed "conductor" before boarding the "train." Passengers sat in a faithful reproduction of a rail car with the exception that a screen was installed at the front. The passengers then went on a journey by viewing images projected on the front screen. ${ }^{2}$ In the more elaborate installations, features were added to enhance the experience, including sound, motion (rocking of the car), lighting, and even a belt with metal fins which travelled beneath the ride, creating a "clickety-clack" noise in order to complete the impression of train travel.

These tours were a popular form of amusement and records of the time indicate that these rides were of equal appeal to people from all walks of life. Unlike the real train tours, however, all seats were "first class."

Whether in an elaborate recreation of a rail car, or just simply sitting in a hall, the great advantage of motion pictures was that it provided for the first time, the ability to recreate the movement of trains and thereby give the illusion of speed and excitement. Previously this excitement could only have been experienced from an actual train ride by a public who in their daily life moved no more quickly than a horse could gallop. Even for the people who were used to train travel, these images were often shot from an angle which could only have been seen by the engineer or brakeman.

The viewers' experience of the moving picture was a recreation of what could only be experienced through a machine, the 
powerful Canadian Pacific Railways (CPR) locomotive, speeding around "dangerous curves;" bursting forth from the inky darkness of a tunnel, twisting, tortuous curves. This was the role in the beginning, much as one experiences an amusement ride / simulator or experiences an IMAX ${ }^{\circledast}$ or OMNIMAX $^{\circledR}$ film today.

The development of motion pictures coincided with the development of active publicity campaigns by the CPR. It did not take the CPR long to realize the potential of the new medium of motion pictures and to capitalize on the public's fascination with trains and motion. It was a natural extension, therefore, for the largest railway concern in Canada to become involved in the production of moving pictures.

\section{Canadian Pacific Railway Company and Moving Pictures}

A Transcontinental rail-line was part of the political incentive given to British Columbia by the Government of Canada to encourage it to join Confederation. The Canadian Pacific Railway was charged by the Federal government to fulfil its commitment of creating a transcontinental railway. In the pursuit of this goal the impact on Canadian life and culture are still felt today. In return, the Canadian government gave assistance and incentives to the CPR to build such a railway. Land grants were made by the Government of Canada to the CPR as part of these incentives.

The enormous construction costs of the transcontinental railline, necessitated that the CPR explore every possible option of generating revenue in order to reduce its enormous debt load and to begin to make the line profitable. The CPR in cooperation with the federal and provincial governments and with the Hudson's Bay Company, developed plans to encourage immigration and settlement to western Canada and the development of agriculture, mining and forestry. In order to meet these objectives the CPR developed an extensive system of promotion which included the use of still photographs, illustrated lectures and testimonial pamphlets.

The CPR was very selective in its choice of people and companies to which it would allow free passage or other forms of assistance. The CPR would choose to facilitate a company or indi- 
vidual either for their celebrity or for their demonstrated ability in order to garner maximum exposure and impact. The CPR was aware that these efforts were of little use unless they reached the intended audience. Therefore, many smaller ventures were turned away if the CPR felt that the product would not reach a sufficiently large or desirable audience. An example of this is found in Van Horne's rebuke of an unknown photographer:

\begin{abstract}
Messrs. Notman and Son undertook a similar work on our line on their own account and without assistance from the Company, and, having both capital and experience, they have been quite successful and have done the Company a great deal of good. ${ }^{3}$
\end{abstract}

The same policy would also apply for filmmakers. Many would vie for the support of the CPR in creating railway films however, only those with a proven record for exhibition and distribution would receive assistance.

CPR filmmaking fell broadly into two categories, those which were designed with a specific intent to educate, inform and persuade and those which were primarily intended as entertainment. The CPR provided the former type of films to lecturers and later distributed them through its overseas offices. These films simply changed "Illustrated Lectures" into "Animated Lectures." These films carried on from the lantern slide tradition and would continue to be used in this same form for many years by private and company agents hired to encourage immigration.

The latter type of filmmaking was "sponsored" by the CPR, to the extent that the CPR provided transport and accommodation, on a semi-exclusive basis. Individual filmmakers approached the CPR with a specific project they wished to pursue. These films provided the security of a corporate contract and allowed for experimentation by the individual cameraman. These entertainment films were distributed by the filmmaker directly through his own catalogues and venues and were not usually available through the CPR offices. The CPR did not define the type of filmmaking rather it facilitated the production of films of contemporary appeal.

Farmers, Phantoms and Princes. The Canadian Pacific Railway and Filmmaking... 


\section{James Freer}

The first filmmaker to be encouraged by the Canadian Pacific Railway was James Freer, who toured Britain in 1899 with a series of films shot near his Manitoba farm. Freer, who had emigrated to Canada ten years previously, was the example of a prosperous farmer and success story which the CPR wished to promote. Additionally, Freer had previously been a newspaper publisher in England.

Although the CPR did not receive any direct acknowledgement in sponsoring Freer's tour, the involvement of both the $\mathrm{CPR}$ and the Canadian government in the production of these films was clearly demonstrated when Lord Sifton, Minister of the Interior, stated :

The CPR has initiated a series of animated photographs of Canada, its scenery and its industries, which is much in demand. Naturally my department cooperates in any efforts that have for their object the dissemination of knowledge about Canada. ${ }^{4}$

Freer's lecture was billed as Ten Years in Manitoba and included "25,000 Instantaneous Photos upon Half-a-Mile of Edison Films." Although it is not believed that any of these films still exist, the titles and published accounts of the day give a good deal of insight into the films' content. Some of the titles given in Freers' 1899 presentation were: Harnessing the Virgin Prairie, Six Binders at Work in 100 Acre Wheat Field, Harvesting Scene with CPR Trains Passing and Comin Thro' the Rye (Children Play in the Hay).

Freers' films provided a backdrop to his lecture in the tradition of the "Illustrated Talks," now using moving images rather than glass slides. The audience who attended his 1899 lecture series were amused, simply by the moving images and Freer's fantastic tales of life of the Canadian prairies.

In the spring of 1902, Freer made a second tour of England with his films and the CPR and the Government, once again facilitated "Freer's Lectures" by supplying passage and travel while in England. This tour was not the success that the first had been, even though the sponsors stipulated that one of two 


\section{BOROUCH OF DORCKESTER}

Thannical Instruetion Committee. TOWN HALL, DORCHESTER.

\section{Friday next, Jan. 27th,} Rt 8 p.m.,

Fis Worship the Mayor (George Davis, Esq.) in the Chair.

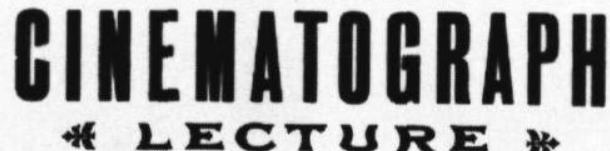
HLUStRated BY, .

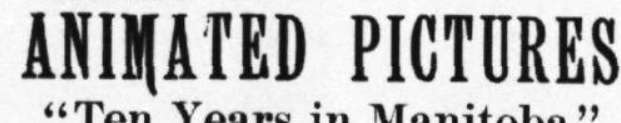
"Ten Years in Manitoba"

\section{Mr. JAMES S. FREER, or Brandon, Manitoba, Canada.}

25,000 Instantaneous Photos upon IIalf-a-Mile of Edison Films, reproducing the following amongst other scenes :

Arrival of C.P.R. Exprens at Winnipeg; Pacific and Atlantic Mail Trains ; Harnessing the Virgin Prairie; Canadian Contineutal Jubilee; Premier Greenway stooking grain ; Six Binders at work in 100 acre wheat field; Typical stooking scene; Harvesting scene with trains passing; Cyclone thresher at work: Coming thro' the Rye (children play in the bay) Changiag the Guarda at is. James' Palace (a exhibited at Windsor Castle); and other aubjects (Masical Aceompanimenta).

Front Seats, 6d., Second Seats, 3d. Thekets may be had at Henry Ling's Fancy Repository, Dorchester, or of A. EDWARDS, Secretary.

lectures must be given in a rural area. The most oft cited reason, verified by the handbills, was that few of the titles had changed. When he returned to Canada, Freer solicited support from the Department of the Interior, the CPR and various Western agencies and associations to fund the production of new titles. It is unclear whether or not he received any support. When in 1906 Freer proposed a third tour, both the CPR and Government officials declined his offer. 


\section{Phantoms and Panoramas}

One of the early popular vaudeville forms of cinema was the so-called "Phantom Rides." These "Phantom Rides" were popular both in Britain and North America. They were linked by the common element of having been photographed from either the cowcatcher or the rear platform of a speeding train. These films were a popular exhibition form between 1898 and 1906 . The CPR was involved with at least two of the Phantom Ride producers, the American Mutoscope Company and Edison.

\section{The American Mutoscope Company}

The CPR's involvement with American Mutoscope was likely two-fold. First, the president of the American Mutoscope Company was George R. Blanchard, one of the most prominent rail executives in America and an acquaintance of Van Horne. Second, American Mutoscope held the reputation for "quality" moving images favoured by first-class theatres. Additionally, American Mutoscope had filmed an extensive number of train subjects. W.K.L. Dickson in July 1896 had filmed a number of films along the tracks of the Pennsylvania Railroad. In the fall he would film perhaps the most popular railway film to date in North America, Empire State Express (1896).

Audiences were thrilled, but also had a voracious appetite for new footage and companies were constantly searching for new material. When American cameramen first came to Canada it was to film Niagara Falls. By 1899, Niagara Falls had already been shot from every angle, above, below, from the electric railway descending into the canyon and from shoals in the middle of the river. Companies wanted new scenes of Canada and what more exciting footage could be obtained than from a train passing through the "Canadian Pacific Rockies?"

To obtain these images, American Mutoscope sent to Cana$\mathrm{da}$, on one of his first solo assignments, a young cameraman by the name of William "Billy" Bitzer in October, 1899. Bitzer recorded a series of short films ranging in length from 27 to 45 feet. An example of one of the titles is, Down Western Slope [Down Kicking Horse Grade, Can. R.R.] (1899). This film is a view from a camera mounted on the front of a train, showing 
on both sides of the track the slope of the mountains, covered with snow and the river running alongside the grade. The action is similar in other titles such as Fraser Canyon (1899) where the camera was again at the front of the train giving an exciting view as the train winds its way through the canyon beside the Fraser River. Gap Entrance to Rocky Mountains (1899) capitalizes on the excitement of travelling over an open trestle, with the mountains obvious in the background:

[...] a series of magnificent panoramic views taken in the Canadian Rockies over the line of the Canadian Pacific Railroad. The entire series has a stereoscopic quality which has occasioned the most enthusiastic praise wherever the pictures have been shown. The scenery is the most magnificent on the North American Continent, and the view, as if one were riding on the cowcatcher of a locomotive running at high speed, is one that even tourists riding over the line are not privileged to enjoy. ${ }^{5}$

In addition to mountain rail scenes, Bitzer also filmed the CPR ship, Empress of India (1899) as it arrives in Vancouver. ${ }^{6}$

\section{Edison}

In 1901, the CPR would assist an Edison cameraman, believed to be Robert K. Bonine, in filming "Panoramic Views" of the Rocky Mountains. Titles ranged from 29 to 200 feet long and were filmed from moving platforms at either end of the train as it travelled through the Rocky Mountains. One example is the title Panoramic View, Kicking Horse Canyon (1901), described as "one of the grandest pieces of scenery in the West, namely, 'Kicking Horse Canon (sic)' on the line of the Canadian Pacific R. R." This film is followed by Panoramic View, Lower Kicking Horse Canyon (1901) which is described:

In this picture we show the ending of this canon (sic), taken from the front of a locomotive on the Canadian Pacific R.R., running through this marvellous scenery at a high rate of speed. The train seems to be running into the mountains of rock as each curve is reached and rounded, making the scene exciting from start to finish. ${ }^{7}$

Farmers, Phantoms and Princes. The Canadian Pacific Railway and Filmmaking... 
In the catalogue descriptions of these films, the CPR is always mentioned, as this was one of the stated conditions made by the $\mathrm{CPR}$ before allowing any company to film or photograph along the line.

\section{Charles Urban and Joseph Rosenthal}

One of the most successful and best known series of moving pictures of Canada is the images created by Joseph Rosenthal when employed by Charles Urban. These films, which would become the Living Canada and later, Wonders of Canada series, were extremely popular titles in the Urban catalogue and received wide distribution throughout Europe and North Ameri$\mathrm{ca}$. The films produced represent the most comprehensive film study of Canada produced to date, for although Rosenthal was charged with producing a specific series of images, the support of the CPR provided him with the opportunity to create a number of additional films.

In April 1902 Charles Urban, while in his position as Managing Director of the Warwick Trading Company, proposed a series of films "illustrating scenery and life throughout Canada, ranching, harvesting." Charles Urban (1871-1945), ${ }^{8}$ an American, was originally sent to England in 1897 by the New York based Maguire \& Baucas to distribute Edison equipment and films. Urban, the consummate salesman, changed the name of the London office to the Warwick Trading Company, reflecting its address in Warwick Court and defusing British antiAmerican sentiment. Urban left the Warwick Trading Company while Rosenthal was filming in Canada, and established the Charles Urban Trading Company, which would distribute Rosenthal's finished films in England.

In a time when moving pictures were beginning to fall into disrepute in some quarters, Urban maintained a reputation for "quality" films. The majority of the Urban catalogue consisted of films which could be considered as, though not called so at the time, newsreel or documentary. Urban's films were moving away from "animated photographs" and "illustrated gazettes" towards a style which would become known as documentary. This combination of respectability and established distribution 


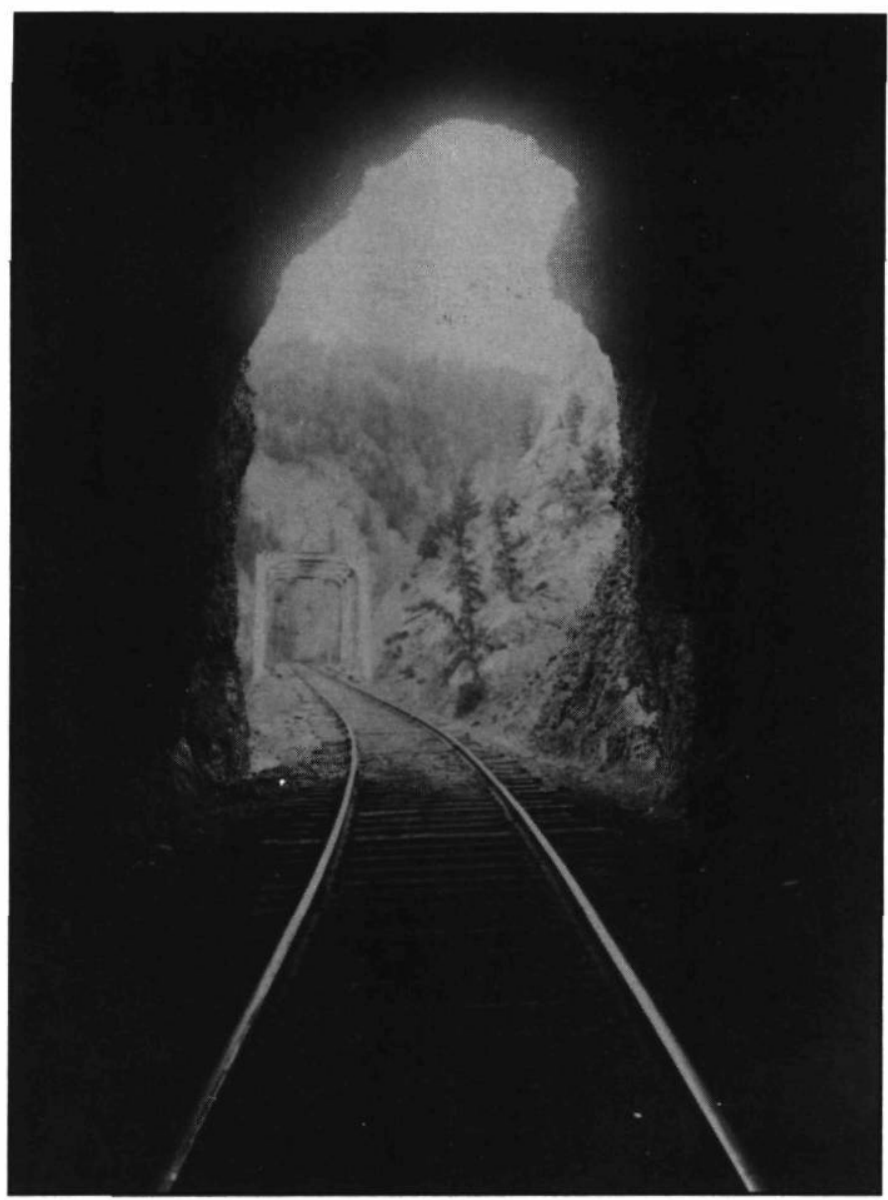

Crossing the Rockies via CPR, Joseph Rosenthal (1903)

Collection British Film Institute

was key in the CPR's decision to cooperate with Urban and his cameramen on what would become the largest investment by the CPR to date in the production of moving pictures.

With American Mutoscope and Edison, the films had been simple "views" in the tradition of the day, presenting exactly that - views of the Rocky Mountains. As these views were 
simple depictions, it is likely that the CPR had little interest in actual production, for there was little to be altered; the CPR provided the passage and facilities where the views were at the most spectacular. However, with Rosenthal, who was to be in Canada for some time, the CPR wished to exercise a little more control over the images which would be acquired and how they would be marketed. One example of this was the insistence of the CPR that it should be prominently recognized in both the catalogue and on the actual title card of the film. At this period in film history, credits of any type were only beginning to appear.

In a letter to Urban from Archer Baker, European Traffic Manager (May 6 1902), the terms of the negotiations are detailed. In keeping with its practice, the CPR was not hiring or funding Urban, rather simply facilitating the production of the filmmaking by providing train passage. The CPR was actually getting quite a good bargain as they agreed to provide one or two free first class return tickets for the route between Québec or Montreal and Vancouver, B.C., including branch lines, exclusive of meals and sleeping berths.

The CPR made several suggestions of the types of scenes they would like included. CPR officials suggested that the operators leave Britain in early July, so as to allow time for taking scenes in the mountains of British Columbia before taking a series of "good ranching and harvesting scenes in Alberta and Manitoba." The CPR made the oft told stipulation that no snow scenes be taken, and also that neither Canada nor the Canadian Pacific Railway be connected with Indian scenes without the consent of the CPR. ${ }^{9}$ Although these conditions were expressed by Archer Baker, it is most likely that the edict disallowing snow scenes came directly from Van Horne. The image of Canada as a frozen wasteland, as portrayed in Kipling's Our Lady of the Snows, annoyed Van Horne to such a degree that no mention of snow would be made in any of the $\mathrm{CPR}$ advertising campaigns during his tenure or lifetime. Even by 1930, snow scenes were only depicted in advertisements for the Winter Carnival and for "skiholidays," regardless of media. It is very likely that it was the British and European reception to the winter scenes which Ro- 
senthal did eventually shoot which were responsible for the CPR's later promotion of winter carnivals. An example of the attitudes which so annoyed Van Horne may be found in the reports of one of the CPR's earlier British lecturers, James Freer. Freer recounted individual Britons telling him of "friend's tales" of cows that had frozen and shattered due to the Canadian cold or of Indians attacking so frequently that one needed " to be armed with a bowie knife, tomahawk and a 44 Winchester repeater."

Rosenthal arrived in Québec at the beginning of August 1902 and set to work the instant he touched Canadian soil. His first picture depicted the landing at Québec of a party of immigrants, who had travelled on the same ship as him. Rosenthal set out with three associates, F. Guy Bradford, Cliff Denham and T. Bell. Bell was a CPR employee whose position was Advertising Agent in Montreal. Bradford and Denham were British but remained in Canada after Rosenthal and had careers in exhibition and distribution. Denham remained in Montreal, establishing a processing facility for the film Rosenthal would shoot. The others left on the CPR heading west, filming the sights as they went to Ontario, the Prairies, and then through the Fraser River Canyon to Vancouver.

Following the CPR's suggestion of ranching films, Rosenthal produced Branding Colts at Alberta, N.W.T. (1903), Rosenthal also produced several films in Manitoba, including Threshing Wheat on a Manitoba Farm (1903) and After the Harvest (1903). The last paragraph in the catalogue description of these films is "A scene full of animation, and one which would be viewed with much interest by the British farmer."

It was the Rocky Mountains, however, which many identified with images of Canada. Rosenthal did not disappoint his audience. Urban marketed these films as having been

[...] taken from a special engine and depict[ing] the glorious scenery of the Rocky Mountains as seen from the Train of the C.P.R.

Note: This picture and the following one differ from all other railway panoramas ever photographed as it does not only show the approaching and passing scen- 


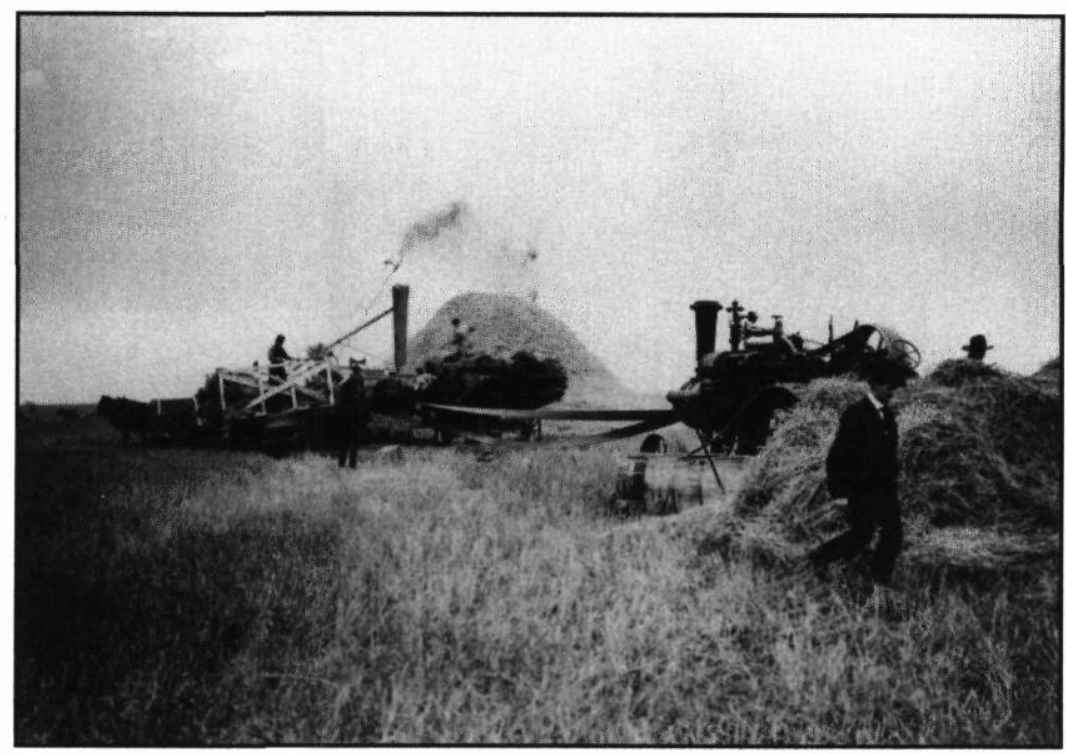

Threshing Wheat on a Manitoba Farm, Joseph Rosenthal (1903)

Collection British Film Institute

ery, but shows the entire train with the puffing engine drawing coaches constantly in view. A new sensation. ${ }^{10}$

When Rosenthal reached British Columbia, he filmed in the Lumber camps, producing Logging in the Canadian Forest (1903). This $300 \mathrm{ft}$ film begins with the Axman supported on a platform and concludes with planks being stacked and the "cuttings" being burned. In addition to the logging films, Rosenthal solicited funding for a film on the B.C. salmon fisheries. Catching 50,000 Salmon in Two Hours: Salmon Fishing on Fraser River (1903) was sponsored by the Anglo British Columbia Packing Co.

These films depicted the immense natural wealth of Canada with fantastic scenes of nature's bounty which were sure to amaze those who dwelled in cities. Although not mentioned as a sponsor, the CPR would be interested in facilitating this activity for several indirect reasons including the sale of timber, the transport of timber and the potential of luring new immigrants to Western Canada.

What series of films depicting Canada would be complete without scenes of Niagara Falls? Rosenthal dutifully shot a series 
of views of Niagara Falls entitled Niagara, the World's Wonder (1903) and A Trip Through the Niagara Gorge on the Electric Railway (1903). These films premiered in London with the Canadian High Commissioner of the time Lord Strathcona (Donald Smith) in attendance in early 1903. Additionally, Bradford and Denham arranged for a Canadian showing to be held in Montreal.

In addition to the films which Rosenthal shot to fulfil obligations to the CPR, an additional body of work was produced providing a glimpse of life in Canada. Rosenthal's depictions were that of a British tourist in Canada rather than what the various government and corporate bodies felt a tourist would like to see. Rosenthal returned from the west and was filming in Montreal by the new year, as his visitor's pass from the Montreal Toboggan \& Skating Club indicates. This pass allowed Rosenthal "and assistant" to rink privileges for one week beginning January 2,1903. It was during this time he filmed Montreal on Skates (1903), Ice Yachting on the St. Lawrence (1903), The Outing of the 'Old Tuque Blue' Snow-Shoeing Club of Montreal (1903) and Tossing the Photographer (1903), although this was likely filmed by one of Rosenthal's assistants.

It was in the spring or early summer that Rosenthal filmed one of his most interesting titles: "Hiawatha," the Messiah of the Ojibway (1903). Hiawatha, perhaps the first dramatic film to be produced in Canada, was based on adaptation of the Henry Wordsworth Longfellow poem, The Song of Hiawatha (1855) by E. A. Armstrong, whom Rosenthal met in Montreal. The catalogue notes that a special score was composed for this film. The film was fifteen minutes long and composed of twenty different scenes filmed near Desbarts, Ontario. Hiawatha was both photographed and directed by Rosenthal in his first role as director.

Hiawatha was billed in the Charles Urban Trading Company's November 1903 catalogue as the "Passion Play of America." The catalogue gives not only a description of each scene, but also an illustrated essay, with photographs from the film, detailing the storyline. Unfortunately, all that is known to remain of this film is its catalogue descriptions.

Farmers, Phantoms and Princes. The Canadian Pacific Railway and Filmmaking... 
Before Rosenthal left Canada he filmed a few additional shorts Indians Gambling for Furs - Is It Peace or War? (1903), The C.P.R. "imperial limited" at Full Speed (1903) and Will the Express Overtake Them? (1903). The reception of these films was such that, although neither the CPR nor the Canadian government had directly sponsored or endorsed these additional films, they generated at least as many benefits to Canada and the $\mathrm{CPR}$ as those which were specifically sponsored.

\section{The Edison Players : the development of narrative structure in film}

With Freer and Bitzer, the involvement had been simple facilitation; with Rosenthal, the involvement had extended to include suggested topics; however, the focus of the films had always been on experiencing the image, the creation of excitement in viewing the image. By 1910, the audience had reached a level of sophistication such that simple motion no longer held the fascination it once had. It is very likely that the Edison people told CPR officials that if they wished films which would distribute and promote themselves, they would have to be of the type which would ensure a wide viewing audience :

Not only will they graphically unfold the story of the great west, pictorially true in every detail, but from the thrilling little dramas, tragedies or comedies realistically played through them by as able and high-class a collection of players as the Edison company could get together, they will attract the attention of all classes. (Rankin, 1910a, p. 935)

While it was a new style of filmic communication, the message which the CPR wished to convey remained the same:

To show to the struggling farmer, through the medium of the moving picture, the premium that western Canada offers for home-making and independence to the man of energy, ambition and small capital; to picture the range cattle, fat and happy, roaming the foothills of the mighty Rockies. (1910a, p. 937) 
The series of films were directed by J. Searle Dawley and photographed by Henry Cronjager. Although the majority of footage was shot along the CPR line, some of the films do feature interior scenes shot later at the Edison Bronx studio.

Supervising the Edison Company for the CPR was John Dennis. Dennis was the head of the CPR's subsidiary, the Canadian Pacific Irrigation and Colonization Company. Dennis had previously purchased projection equipment from Edison for the CPR Pavilion at the Alaska-Yukon-Pacific Exhibition of 1909. It was likely at this time that the possibility of producing a sponsored series of films was discussed. It has been suggested that the switch from Urban to Edison signalled either displeasure on the part of the CPR or a change of focus in marketing to Americans rather than Europeans. Perhaps the most valid answer is the relative styles of filmmaking. An article of the time denotes an awareness of the growing sophistication of the film audience:

\begin{abstract}
[...] the great mass of the public want to be amused and entertained, not instructed, and if they are to be educated it must be in a subtle, delicate manner, absorbed, as it were, unconsciously, through the interest that the story itself creates in the minds of the audience. What does Johnny the conductor from East Harlem care about the mining industry in Southern British Columbia, or the ranching of Alberta? Not a rap. Not a jot, nor a tittle.

But if the class of story that appeals to Johnny and his girl runs prominently through mining, or lumbering, or fishing, or ranching films, they will unconsciously swallow the knowledge. (Rankin, 1910b, p. 28)
\end{abstract}

Indeed, it would have been hard for the "mass of the public" to miss the references to the CPR. One of the titles, The Swiss Guide (1910) was set in the CPR hotel at Lake Louise. Ted Hart has documented in The Selling of Canada how the creation of a Canadian Alps had long been part of the CPR promotional materials. A Wedding Trip from Montreal to Hong Kong (1910) begins with "Lovey" (the new husband) missing the CPR transcontinental leaving Windsor Station in Montreal and ends with "Lovey" falling into the smokestack of the CPR steamship 
Empress of India. Along the way, the happy couple have adventures in the CPR Banff Springs Hotel.

Other titles in this series included: The Cowpuncher's Glove (1910), the life of a "cowpuncher" in Calgary with scenes of the Stampede; Life of a Salmon (1910), which depicted West Coast natives in costume, fishing, racing canoes and dancing in front of the CPR Empress Hotel in Victoria. The Song That Reached his Heart (1910), featured an Edison phonograph as a pivotal plot device. A young man had gone West to seek his fortune, and, while gaining wealth, had lost the woman he loved. $\mathrm{He}$ is saved by hearing her voice on a gramophone cylinder.

The films in this series were released by Edison at a rate of about one a week throughout the fall and winter of 1910. Reviews of the day indicate that this series of films received wide distribution and was popular with a wide audience. "

\section{Return to the Spectacle Films}

With the development of narrative and longer films, the CPR might have continued in the vein of the Edison films, producing short fictionalized accounts of life, courtesy the CPR. The difficulty with these films was exactly their subtlety. The resultoriented managers at the CPR did not directly perceive the benefit to the Company. In fact, although popular with audiences, the CPR passenger agents criticized the films as being too vague. What they desired, was the story of a young man taking possession of a "ready-made farm" or of a family emigrating to their "new prairie home." Eventually the CPR would produce these films through its own subsidiary; however, the intervening time, "spectacle films" continued to hold appeal and the CPR continued to facilitate their production.

One of the greatest cinematic achievements of its time was Kinemacolor. Billed as the first "natural color" process, it was invented by British chemist George Albert Smith in 1906. Smith's labours had been encouraged and funded by Charles Urban, who had a fascination with the concept of colour cinematography as early as 1901. It was Charles Urban, as director of The Natural Color Kinematograph Company, who promoted Kinemacolor. Kinemacolor was the only commercially viable 
natural colour process prior to 1920 and was projected at select theatres in England, Europe and North America. Approximately a million feet of Kinemacolor negative stock was exposed, depicting of a wide variety of scenery and events, from natural wonders to the Delhi Durbar.

Following on the success of his Living Canada series, Urban again sent cameraman to Canada, this time to record its people and wonders in colour. Once again, the CPR facilitated Urban in his undertaking, and received credit both on the completed films and in the catalogue.

When Kinemacolor set out to harness the gorgeous beauties of Nature among the Rocky Mountains of British North America, the Canadian Pacific Railway, which cooperated in the enterprise, provided a special engine attached to a darkroom on wheels. This "Kinemacolor special" moved at leisure among the snowclad giants, and some very impressive and beautiful pictures were obtained to delight vast concourses. (Talbot, p. 126)

Several films were produced of varying length from a topical to a multi-reel extravaganza. The longest film was the four reel (5125 ft), From Nova Scotia to British Columbia (1911). In addition, a separate one reel film (1100 ft) of Canada's best known natural spectacle, Niagara Falls (1911) was also produced. Other shorter films included images of the Canadian National Exhibition and Northwest Mounted Police.

Unfortunately, few Kinemacolor films have survived and none of the Canadian titles are known to exist. Urban's patent on the Kinemacolor process was challenged in Britain and, in an ironic twist of fate, Urban's defence of simply using "well known principles of physics" worked against him. Although the court believed Urban, it revoked his patent protection exactly because they believed that you could not patent well known principles of physics. Urban was very ill at the time of this announcement and lost interest in Kinemacolor. Without Urban's enthusiastic support and patent protection, Kinemacolor soon faded. ${ }^{12}$

In 1919, Charles Urban would once again approach the CPR to solicit its involvement in producing a documentary film of 
the Prince of Wales' tour of Canada. Some sources are of the opinion that the CPR was the star of the film, not the Prince of Wales. The dialogue stressed the strength of the mighty CPR engines, the luxury of the Prince's rail car and the CPR hotels, the punctuality of the timetable and the courtesy of the staff. The film was designed not so much as a document of the Prince's travels, but designed to lure those who wished to travel like a prince. The film was very popular and received wide distribution throughout North America, Europe and the Commonwealth.

With the success of the Prince of Wales tour film and in conjunction with the emerging British and Canadian immigration policies, the CPR turned its filmmaking focus back to the promotion of Canada and Canadian industries and resources. Charles Urban proposed to the CPR, a partnership to develop a stable film production company in Canada. Urban's proposal was to lead to the eventual establishment of Associated Screen News of Canada Ltd., with the CPR as the major financial contributor, and thereby begin another chapter in the CPR's role as a "facilitator" in the development of film in Canada.

With the end of the War, the CPR and the Federal government would again direct a great deal of attention to the development of the Canadian West. The Government of Canada launched a number of initiatives to encourage returning veterans and (primary) British immigrants to farm in the West. Motion pictures would form a major role in the communication of these opportunities; however, based on previous experience, senior officials at the CPR decided that it would be advantageous to create the films "in house" as the CPR already did for still photographs and posters.

Urban, Dennis, the new CPR president Edward Beatty, ${ }^{13}$ and John Murray Gibbon, the General Publicity Agent, decided in the early months of 1920 to create a motion picture production unit within the Advertising Department. To lead this unit, they recruited Bernard Norrish from the Department of Trade and Commerce, Exhibits and Publicity Bureau (with whom the $\mathrm{CPR}$ had a great number of previous dealings). It was then decided to establish this unit as a separate corporate entity (al- 
though the CPR remained the majority stakeholder) in order to facilitate the new company's ability to solicit other film contracts and offset capital expenses. This new company was Associated Screen News of Canada Ltd. which would play a pivotal role, due primarily to the stable support of the CPR, in the development of film production in Canada.

\section{National Archives of Canada}

\section{NOTES}

1 For more information of Hale's Tours and Scenes of the World, see Raymond Fielding, "Hale's Tours: Ultrarealism in the Pre-1910 Motion Picture," Before Griffith (Berkeley, Los Angeles, London: University of California Press, 1983).

2 These devices were a reproduction of earlier devices where canvas had been wound past passenger windows.

3 Letter dictated by Van Horne, 9 March 1899 (Van Horne Letterbooks, National Archives of Canada).

4 Report, from the Department of the Interior (Ottawa: King's Printer, 1899, p. 114).

5 Description from the American Mutoscope of Biograph Catalogue, November 1902 , p. 125.

6 The film is titled, incorrectly, Steamship "Express of India. "In the print, however, one can see clearly that the correct name of the vessel is Empress of India.

7 From the Edison Catalogue, 1904, p. 15.

8 Charles Urban was more of an astute businessman and entrepreneur than a filmmaker, although he was responsible for several developments in the history of film. In a general sense, Urban was a strong proponent and creator of what would become known as the newsreel and travelogue. His firm created and distributed a wide variety of educational and scientific films including a series for use in teaching modern surgery techniques (1910). One of his best known accomplishments was the invention and promotion, with G.A. Smith, of "Kinemacolor, " one of the first practical colour processes. In a legal patent-battle, full of intrigue, Urban's Kinemacolor patent was rejected and the process fell into obscurity. Urban returned to North America shortly afterwards and began producing and distributing educational pictures in New York.

9 "Letter from Archer Baker to Charles Urban", May 16, 1902. From British Film Institute, Joye Collection.

10 From List of Urban Film Subjects (London: Charles Urban Trading Company, november 1903).

11 In total, thirteen films were produced. According to Library of Congress Copyright records they were: The Life of a Salmon, A Trip Over the Rocky and Selkirk Mountains, A Wedding Trip from Montreal to Hong Kong, An Unselfish Love, The Song That Reached his Heart, Riders of the Plains, More Than his Duty, The Cowpuncher's Glove, The Stolen Claim, The Little Station Agent, The Swiss Guide, The Ship's Husband.

Farmers, Phantoms and Princes. The Canadian Pacific Railway and Filmmaking... 
12 For more information on Kinemacolor see D.B. Thomas, The First Colour Motion Pictures (London: Her Majesty's Stationary Office, 1969).

13 Edward Wentworth Beatty, later Sir Edward Beatty, became the first Canadianborn President of the CPR in 1918.

\section{REFERENCES}

Barsam, Richard M. Non-Fiction Film: A Critical History. Bloomington, Indianapolis: Indiana University Press, 1992.

Bowser, Eileen. The Transformation of Cinema, 1907-1915. Berkeley, Los Angeles, London: University of California Press, 1994.

Eagle, John A. The Canadian Pacific Railway and the Development of Western Canada. Kingston, Montreal, London: Queen's University Press, 1989.

Hedges, James B. Building the Canadian West. New York: The Macmillan Company, 1939.

Lamb, W. Kaye. History of the Canadian Pacific Railway. New York: Macmillan, 1977.

Morris, Peter. Embattled Shadows: A History of Canadian Cinema 1895-1939. Montreal: Queen's University Press, 1978.

Musser, Charles. The Emergence of Cinema:The American Screen to 1907. Berkeley, Los Angeles, London: University of California Press, 1994.

Rankin, Norman S. "With the Edison Players Across the Continent". Man to Man Magazine, vols. 6-7 (1910a) p. 934-940.

Rankin, Norman S. “Interview with J.S. Demis”. Man to Man Magazine, vols. 6-7 (1910b).

Talbot, Frederick A. Moving Pictures: How They Are Made and Worked. Philadelphia: J.B. Lippincott Company, 1912.

Thomas, David B. The First Colour Motion Pictures. London : Her Majesty's Stationary Office (A Science Museum Monograph), 1969.

Walls, Howard Lamarr. Motion Pictures 1894-1912. Washington: Library of Congress, 1953. 